\title{
Mechanism For The Development Of The Education Market In The Context Of Economic Transformation
}

\author{
Hamidova Aziza Abdufattoevna ${ }^{a}$
}

${ }^{a}$ Researcher, Samarkand State University.

Article History: Received: 11 January 2021; Accepted: 27 February 2021; Published online: 5 April 2021

\begin{abstract}
This article describes characteristics of price and demand for educational services in the market of educational services, interdependence of education and production, structural changes in the system of higher education, characteristics of individual demand for educational services, internal and external factors, level of demand for educational services. The factors of individual competitiveness as an element were studied.
\end{abstract}

Keywords: Education Market, Price, Demand, Supply, Higher Education System, Factors, Demand Diversification, Individual Competitiveness, Price Factor.

\section{Introduction}

The development of the market for educational services is a means of increasing the demand for skilled professionals, and the training of professionals is measured by their position in the market. As a result, higher education institutions need to develop new strategies to develop graduates' skills in the new socio-economic environment.

Educational services are a socially important commodity associated with intangible goods, intangible benefits. Educational services always require improvement and enhancement of their provision, so problems with improving the quality of education arise in any socio-economic environment.

Educational services, like other social benefits, have characteristics of internal and external efficiency. The intrinsic effect on the need for education services is that anyone seeking to improve their vocational training potential will be able to increase their individual returns to education in order to earn a higher income than others. The positive externalities are reflected in the volume of GDP in which important policy decisions are made, in the rate of growth in productivity.

The education market today consists of all the interconnected elements of a socio-economic system that is complex in a consumer market. To be the main generator of this system is undoubtedly society's need to train qualified specialists who will become a unique commodity in the labour market. Therefore, under the conditions of economic transformation, the study of ways to improve the mechanism of educational services market development acquires particular importance.

\section{Literature Review}

The fundamentals of the problems related to education, market of educational services, demand and supply of educational services, increasing efficiency of educational services, ensuring integration of education, science and production, development of innovation in education Keynes J.M. [2], Schumpeter J.A., [10], Porter M.Y. [7], Santo B.S. [9] studied in the 19th century.

Features of Educational Services Market, Investment and Marketing in Higher Education, Pricing of Educational Services, Interrelation of Educational Services Market and Specialist Labour Market, Graduate Employment, Business Management in Higher Education, Development of Educational Services, Higher Education Rating Study Saidov M.H. [8], Lukashenko M.A. [4], Atlukhanov A.A. [1], Bedrachuk I.A. [3], Milgi T. [5], Nasimov D.A, Arabov N.U., Khomitov K.Z. [6].

\section{Research Methodology}

The study uses a dialectical and systematic approach to the study of economic systems and relations, integrated assessment, comparative and comparative analysis, statistical and dynamic approaches and grouping methods to improve the development mechanism of the educational services market and assess the price level.

\section{Analysis and Results}

Let us consider a mechanism for shaping the market for educational services. It is known that demand formation is influenced by a set of differentiated factors. Education includes traditional factors, such as the cost 
of educational services, increase or decrease in income of consumers, image and identity of producers, form of organization ownership, accreditation status, degree of education individualization [4]. An important direction of educational services market development is the orientation of graduates to the international labour market and strengthening its links with the national economy as the final consumer of educational products.

The market of educational services should be focused primarily on the prospects of socio-economic development of the region, with the leading role in the sphere of material production. It is known that it will not be possible to significantly change the ratio between the tangible and intangible sectors in the coming years. At the same time, the structure of training highly educated professionals is very close to the employment structure of the population in developed countries (for example, in the USA $30 \%$ of the working-age population is employed in material production). However, this does not reflect real employment in the republic's economy. For example, in 2018, the country employed $41.5 \%$ of the population in material production (industry, agriculture); the proportion of highly educated professionals in these sectors is less than $40 \%$ of the number of highly educated professionals working in the country. [11]. Therefore, the concept of higher education development and socio-economic development programmes should be elaborated carefully to avoid staff shortages in the sphere of material production. This allows professionals to plan the development of the labour market.

The following results are considered as indicators of the level of socio-economic development of the Republic of Uzbekistan and the level of education of society (Table 1).

Table 1. Main indicators of socio-economic development of the Republic of Uzbekistan [11]

\begin{tabular}{|c|c|c|c|c|c|c|c|}
\hline \multirow{2}{*}{ № } & \multirow{2}{*}{ Indicators } & \multirow{2}{*}{ Unit of measurement } & \multicolumn{5}{|c|}{ Years } \\
\hline & & & 2015 & 2016 & 2017 & 2018 & 2019 \\
\hline 1 & Average annual population & A thousand people & 31298,9 & 31847,9 & 32388,6 & 32956,1 & 33580,7 \\
\hline 2 & Gross Domestic Product & Billions of sums & 171,8 & 198,9 & 249,1 & 407,5 & 511,8 \\
\hline 3 & $\begin{array}{l}\text { Gross domestic product } \\
\text { (compared to last year) }\end{array}$ & $\%$ & 7,4 & 7,8 & 5,3 & 5,1 & 5,6 \\
\hline 4 & Investments in fixed assets & Trillions of sums & 41,7 & 49,8 & 60,7 & 107,3 & 189,9 \\
\hline 5 & $\begin{array}{l}\text { Number of specialists } \\
\text { studying in public higher } \\
\text { education institutions }\end{array}$ & $\begin{array}{l}\text { Number of } \\
\text { professionals per } \\
10,000 \text { population }\end{array}$ & 84 & 84 & 91 & 108 & 120 \\
\hline
\end{tabular}

If we look at the analytical data, the number of specialists studying in higher education institutions per 10,000 population was 84 in 2015 and 120 in 2019. This figure is much lower than in the CIS countries.

It should be noted that as a result of changes in the education system, there may be a "point" of demand for certain specialists and it will be met by educational institutions of the republic, for a number of reasons may not be closed by other regions and educational institutions. First of all, the market of educational services has its own characteristics, which differ sharply from the commodity, information, financial and other markets.

The shortage of human resources requires significantly more investment to train them than other resources. Therefore, accurate planning and management of human resources is important for both the enterprise and the region [6].

Naturally, educational services belong to the group of services (goods) of social significance for society and the population. Its features should be taken into account both in determining the price and demand for these services. In our opinion, the demand for these services is determined by the following key factors:

- Firstly, the need for qualified specialists in industry and other sectors of the economy;

- Secondly, the need for individuals to improve their educational attainment.

At present, the need for individuals to improve their educational attainment is not considered fully determinant of aggregate demand for a number of reasons, but as a country's financial situation and level of education increase, this need will continue to grow.

In most cases the demand for education is directly or indirectly shaped by production, the state and prospects of which depend on the direction and volume of educational services. The following factors affecting production can be distinguished:

- Public policies in the location of productive forces (at national and local levels); 
- Non-state investments that determine the prestige of the industry;

- Innovative technologies, new products (services).

Underlying all of the factors mentioned above is the need to meet the specific needs of society. In other words, the economy of the region must be shaped by these very requirements. Naturally, the task before us is to change the complex structural composition of production in order to ensure that it is effectively shaped to meet the needs of society. The staffing of the Economic Development Programme will be carried out by educational institutions, so that they will not be neglected in future plans for the sector. Such participation implies the existing institution-industry relationship in the development of economic innovations.

The opening of new professions in demand on the market should be carried out along the following lines:

- in accordance with the demand of the population for professions - development of the humanities and socio-economic spheres;

- In line with the country's socio-economic development concept - in addition to the development of traditional industries in the country, mining, tourism, geology and sports will be developed in the near future.

The impact of educational institutions on industry varies from the production of new machinery and technology to the training of specialists in the use of their capital (economic independence and the development of the trade and production base of the educational institution).

In the context of economic modernisation, there is a gap between the demand for specialists for business entities and the demand for educational services on the part of enterprises and the population. Hence, the prospects for the development of production programmes in accordance with the qualification requirements for personnel based on the needs of enterprises. Although this forecast is complex and multi-factor, its methodology is quite well developed.

The demand of enterprises today determines short-term needs, medium-term investment development needs and long-term innovation development needs. Enterprises are often willing to pay for the acquisition of specialists in the medium term, while in the short term they are mainly willing to pay for the acquisition of educational services for their specialists (Figure 1).

The difference between the demand of the population for educational services and the demand of businesses tends to increase in the strategic perspective, which is due to the increasing role of education.

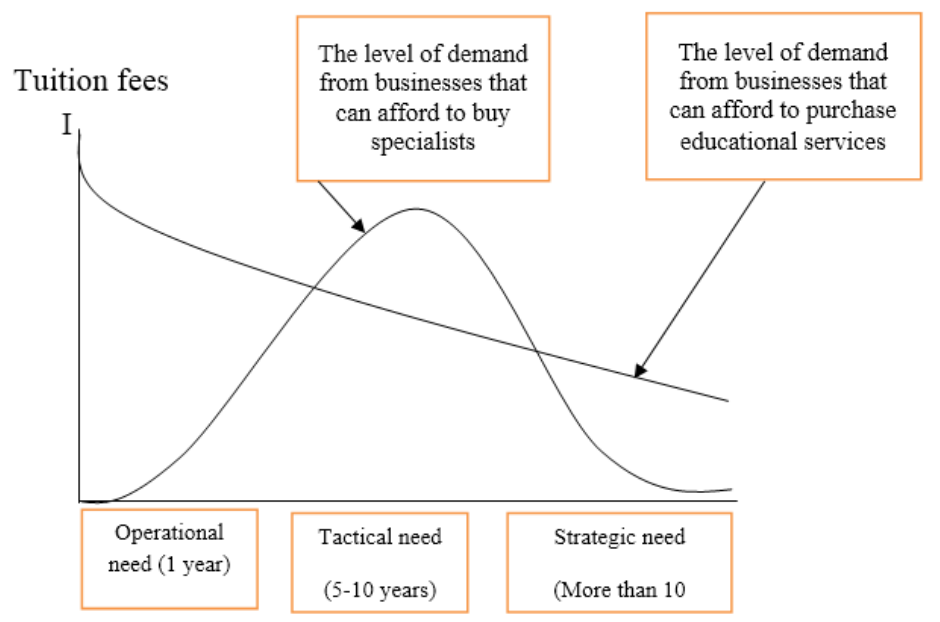

$\mathrm{T}-$ The period of forecasting the need for specialist staff in the enterprise.

Figure 1. Readiness of enterprises to receive specialists and educational services ${ }^{1}$

It is well known that demand determines the needs of the population, which are specifically accepted for each individual, and their ability to meet financial needs. The population's demand for educational services is determined by a number of factors. The composition of the population's demand can be seen horizontally and vertically. The demand for education at personal life stages of the population is determined by age periods. External and internal demand is determined by self-expression factors.

${ }^{1}$ Developed by the author 
As can be seen from Table 2, a number of factors indicate a dynamic characteristic of the demand for educational services, shifting from external to internal self-development factors and vice versa.

Table 2. Description of the individual's demand for educational services ${ }^{2}$

\begin{tabular}{|c|c|c|c|}
\hline № & $\begin{array}{l}\text { Stages of a person's } \\
\text { life activity }\end{array}$ & $\begin{array}{l}\text { An interrelated external } \\
\text { demand of a person }\end{array}$ & An individual's internal demand \\
\hline 1. & Childhood (3-7 years) & $\begin{array}{l}\text { Pre-school education and } \\
\text { upbringing }\end{array}$ & Creative interests, clubs \\
\hline 2. & $\begin{array}{l}\text { Adolescence } \\
\text { ( } 7-15 \text { years })\end{array}$ & General basic education & Creative interests, clubs, courses \\
\hline 3. & $\begin{array}{l}\text { Awkward age } \\
(15-17 \text { years })\end{array}$ & General secondary education & $\begin{array}{l}\text { Creative interests, courses, primary vocational } \\
\text { education }\end{array}$ \\
\hline 4. & Youth (18-25 years) & Vocational education & $\begin{array}{l}\text { Creative interests, courses, additional } \\
\text { professional education }\end{array}$ \\
\hline 5. & Maturity (26-45 years) & $\begin{array}{l}\text { Vocational retraining and } \\
\text { growth }\end{array}$ & $\begin{array}{l}\text { Additional vocational education, vocational } \\
\text { education diversification, hobby }\end{array}$ \\
\hline 6. & $\begin{array}{l}\text { Work experience }(46- \\
60 \text { years) }\end{array}$ & $\begin{array}{l}\text { Professional growth, self- } \\
\text { management }\end{array}$ & Additional vocational training, hobby \\
\hline 7. & Old age (over 60 ) & Self-management & Hobby \\
\hline
\end{tabular}

Educational services can be divided into basic, variable and diversified demand levels according to the level of satisfaction of individual needs (Figure 2).

The basic requirement is related to the traditional notions of the formation of labor functions of human capital, aimed at realizing the potential of those involved in socio-industrial relations as a level of labor resources.

Variational demand is aimed at changing the place and role of the individual in society, as well as changing internal needs and goals.

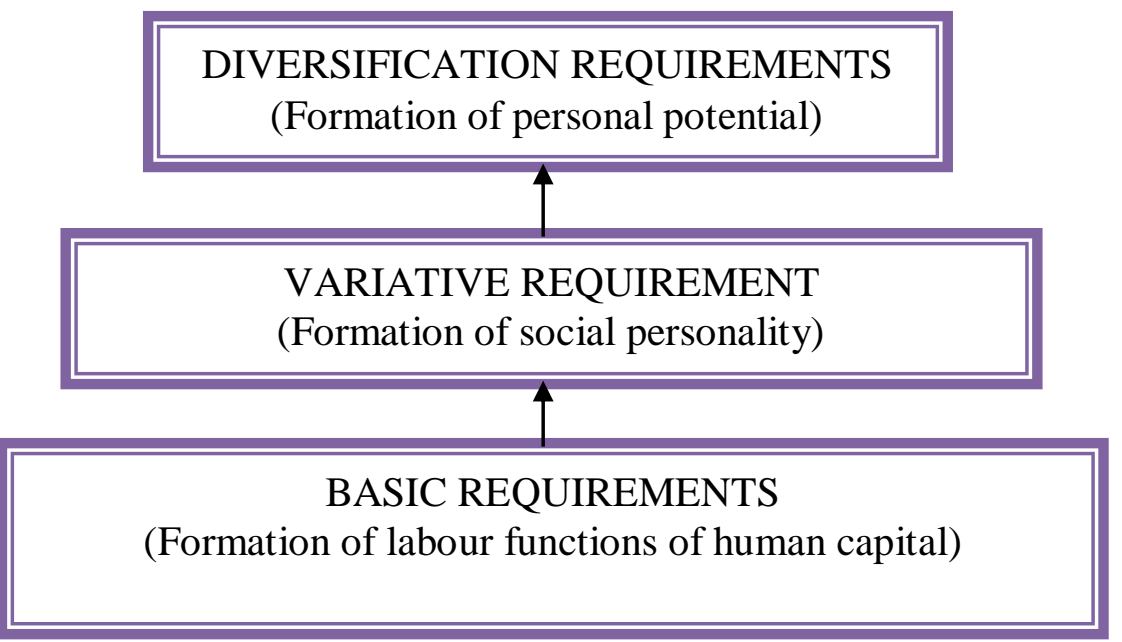

Figure 2. The level of demand of the population for educational services

The need for diversification is the opportunity to change one's place in society by enhancing one's professional skills and career. Consequently, a person's overall need for educational services is the same in every period, i.e:

$$
T=T_{\text {basis }}+T_{\text {divergence }}+T_{\text {variation }},
$$

Ideally, the object of an educational institution's activities should be the aggregate human need for educational services at all stages of human life.

${ }^{2}$ Developed by the author 


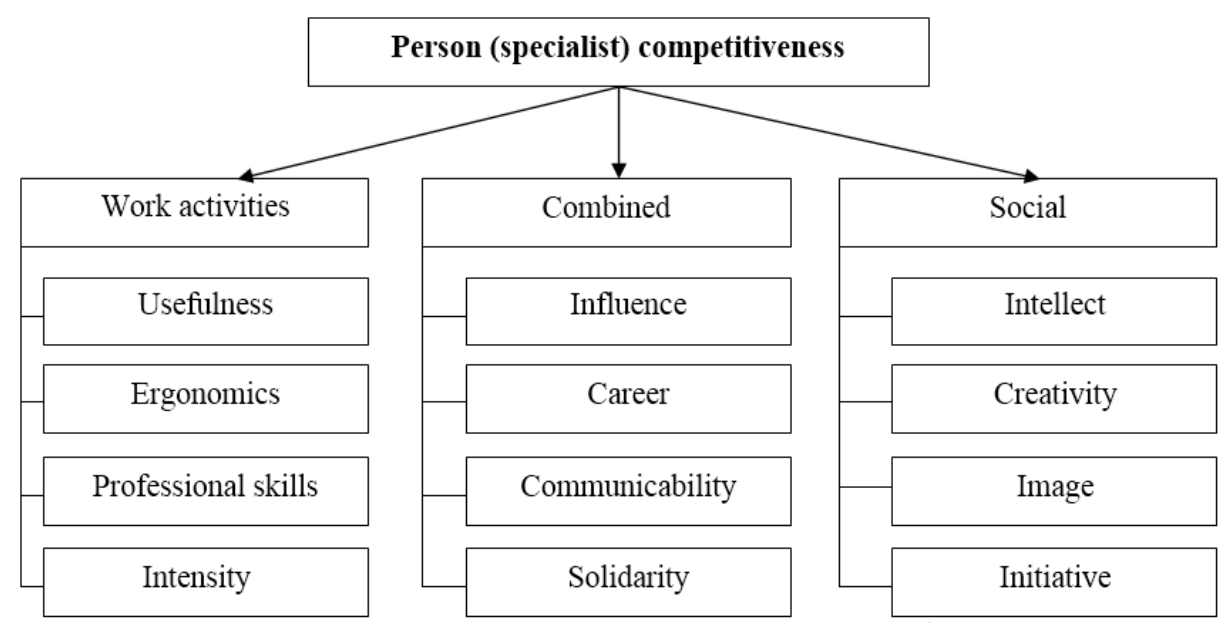

Figure 3. Individual competitiveness factors ${ }^{3}$

An important component of demand formation is to ensure the competitiveness of the individual (Figure 3).

Competitiveness is determined on the basis of the formation of a classification of labor activity, combined and social factors.

The competitiveness of labor activity is based on the need for utility, ergonomics and intensity, while the level of professionalism arises directly and is driven by the demand for production specialists.

On the basis of combined competitiveness, prestige of the profession, career growth, level of communicability and solidarity are the factors of alternative choice of jobs, which are formed in both enterprises and the population, which are consumers of educational products.

At the heart of social competitiveness lies the factors of intellectual potential, creative development of the individual, the growth of his image and personal initiative, as well as factors that are directly related to consumers of educational services.

\section{Demand}

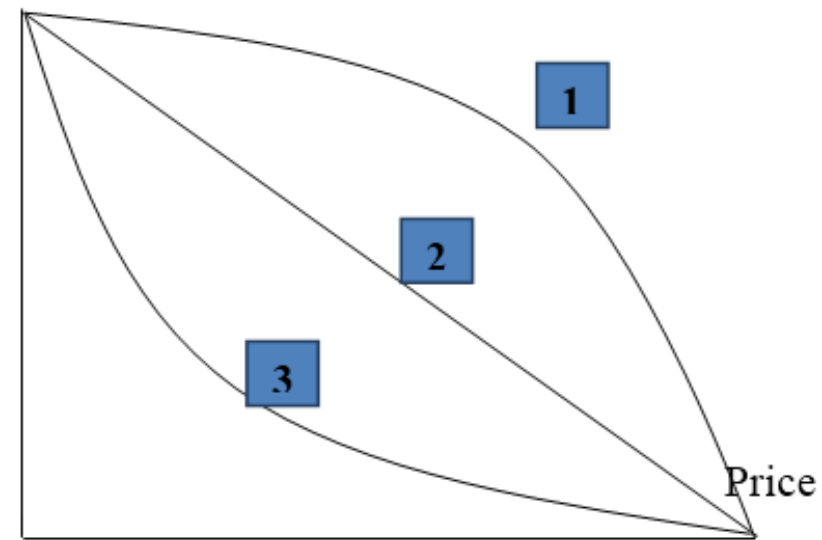

Figure 4. Influence of price factor on population demand ${ }^{4}$

In our view, the dependence of demand on valuation factors in the market is considered by universities within the range of vocational education services (Figure 4).

There are currently three groups of educational services on the market:

- prestigious on-demand services that do not lead to a decrease in demand for educational services (entrepreneurship education, licensed education, prestigious specialties;

- public demand services;

${ }^{4}$ Developed by the author. Here: 1 - prestigious risk education services; 2 - public demand education services; 3 - Price-based risk education services. 
- $\quad$ services on demand (demand for "working" professions in technical specialties.

However, demand is also influenced by non-price factors. The influence of the price factor on educational services is enormous.

The main factors determining the characteristics of educational services. For consumers, the description of the price of these services is two-way. Currently, these services are provided both on a fee basis (paid by consumers) and free of charge.

Consumer demand determines the paid and free choices, which are governed by different factors and supports, which are almost identical in terms of the quality of educational products. The natural state of consumers is the desire for free educational services.

Turning to the market for educational services, it is known that the supply function depends on the influence of cumulative stratified factors on it. These include the cost of educational services, the cost of production factors (rent, teachers' salaries, the cost of information resources, etc.), New educational technologies, the number of students.

Foreign experience shows that the market model of education implies not only the presence of non-state educational institutions, but also a change in the role and functions of state educational institutions as economic entities due to the intensification of extra-budgetary activities and entrepreneurship.

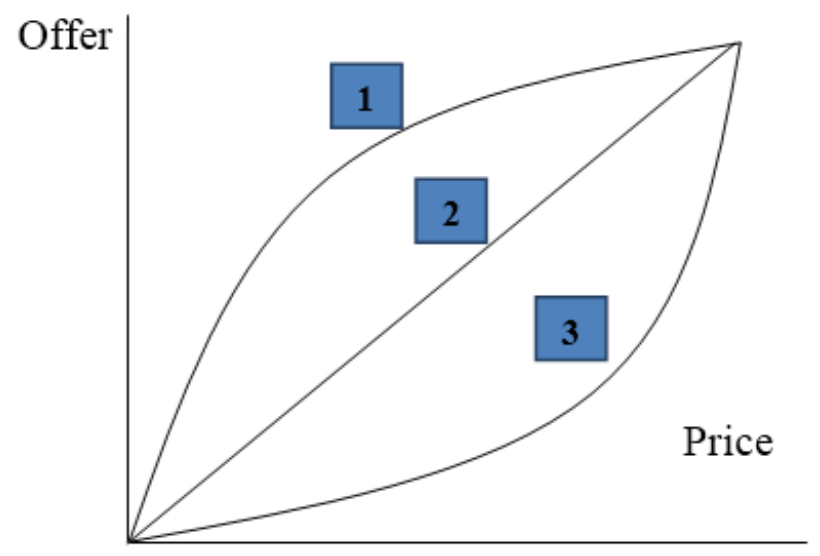

Figure 5. The effect of the price factor on supply ${ }^{5}$

The lack of high barriers to network access and relatively low capital intensity make education services an attractive sector of the economy. In recent years, the establishment of cooperation in higher education in the country on the basis of joint programmes with foreign and CIS higher education institutions for training students has created a competitive environment in higher education. This process is expanding year by year and cooperation with higher education institutions of foreign countries is increasing.

Education is a commodity with moderate elasticity, so price changes within a certain range have little impact on demand, and the market is profitable for entrepreneurs. The dependence of market supply on price factors can also be considered within the range of vocational education and training services (Figure 5).

\section{Conclusion/Recommendations}

Changes in the price of educational services depend on the pricing strategy implemented by the university, the level of pricing, its role and position in the regional market for educational services. Therefore, at the price comparison stage, it is necessary to take into account the price ratio calculated in different ways. Then the lower price step, determined by the cost method, can also be reduced by changing the initial cost base (number of groups, labour norms, etc.). The upper limit is the maximum number of students who can study in these academic areas according to the norms.

The following conclusions have been drawn about the mechanism of mutual supply and demand in the market of educational services:

${ }^{5}$ Developed by the author. In this case: 1 - High-income educational services; 2 - Moderately profitable educational services; 3 Educational services with serious barriers to entry. 
- An increase in demand for educational services across a range of specialties leads to an increase in supply if this is in line with the objectives of the education system actors;

- A decrease in demand for individual specialties will not lead to a decrease in supply as part of a targeted learning strategy for the further development of modern sectors of the economy;

- The period of influence of supply on changes in demand is one to two years under tactical management, the period of demand satisfaction (influencing its formation) is five to seven years under strategic management.

\section{References}

1. Atlukhanov A.A. Improvement of the sphere of educational services: the material and technical aspect: $\mathrm{PhD}$ thesis in Economics. Makhachkala - 2009. - C. 26.

2. Keynes J.M. General Theory of Employment, Interest and Money. Translated by Prof. N.N. Lyubimov, ed. by Prof. L.P. Kurakov. - Moscow: MIEMP, 2010.

3. Bedrachuk I.A. Rating model of department performance evaluation in the system of strategic management of university. Territory of new opportunities: Bulletin of VSUES. 2009. № 2 (2). - C. 220-225.

4. Lukashenko M.A. Higher education institution on the market of educational services: topical problems of management - Moscow: Market DS, 2003. -358 p.

5. Milguy T.P. Peculiarities of educational market development in a competitive environment. Vestnik of Altai State Agrarian University. - 2009. - № 1. - C.79-83.

6. Nasimov D.A., Arabov N.U., Khomitov K.Z. Flexible employment prospects in cis countries. International journal of scientific \& technology research volume 9, issue 02, february 2020.

7. Porter M.Y. Competitive Advantage: How to Achieve High Performance and Ensure Its Sustainability, translated from English by E. Kalinina. - Moscow: Alpina Publisher, 2008 (2nd ed. - 2008). - 720 p.

8. Saidov M.H. Economics, Investment and Marketing of Higher Education. - T.: Moliya, 2002. - 332 p.

9. Santo B.S. Innovation as a means of economic development. Santo B.S. - Moscow: Progress, 1990. $295 \mathrm{p}$.

10. Schumpeter, J.A. (2004). History of Economic Analysis in 3 vols.

11. Statistical collection. State Statistics Committee of the Republic of Uzbekistan. - Tashkent: 2019. - 284 p. 